\title{
Schlay Georgina
}

\section{AZ ELTE KULTURÁLIS JAVAINAK, KUTATÓ ÉS OKTATÓ GYÜJTEMÉNYEINEK SORSA}

\begin{abstract}
Georgina Schlay: The fate of cultural collections, research and educational collections of ELTE

In this study, I present the foundation, fate and current position of the cultural assets, scientific and educational collections of ELTE, sketched and highlighted due to their limitations, and linked to the turning points of university history in an international context. My aim is to highlight the fact that the issue of university heritage is present at universities with a history, very similarities are found in the fate of university collections, and different strategies for managing and coordinating university collections have been developed, taking into account institutional characteristics. can also be used on.
\end{abstract}

Az Eötvös Loránd Tudományegyetem fennállásának 385 éve alatt számos kutatás, tanulmány, képes kiadvány foglalkozott e nagy múltú intézmény történetével. Ezekben kiemelt helyen szerepelnek azok az egyedülálló kulturális javak, amelyek az egyetem alapításával, bővítésével és költözéseivel kapcsolatosak, mint például a Pázmány Péter által kiadott alapítólevél, a rektori és dékáni láncok, a karoknak ajándékozott pedumok, de számos értékes tárggyal, dokumentummal folytathatnánk a sort. Azonban az egyetem örökségéhez nem csak az egyedi tárgyak tartoznak, hanem a különböző karokon alapított tudományos és oktató gyüjtemények is, melyek alapítása és a sorsa együtt változott az egyetem igényeivel és az intézményt ért külső hatásokkal.

Az ELTE Egyetemi Könyvtár és Levéltár 2019. októberében tartott konferenciáján az egyetem néhány muzeális gyüjteményének képviselője, gyüjteménykezelöje vett részt. A szervező célja az volt, hogy megtörténjen az első lépés az egyetemi gyüjtemények diskurzusában. A szakmai napon elhangzott elöadások röviden ismertették néhány egyetemi gyüjtemény történetét, kezelésének és bemutatásának lehetőségeit. Ezenfelül Claudia Feigl, a Bécsi Egyetem Egyetemi Könyvtárának gyüjteményi koordinátora előadásában betekintést engedett abba, hogy az ő intézményükben milyen keretek között múködik a majdnem 100 darab egyetemi gyújtemény szakmai koor- 
dinálása. A két egyetem közötti párbeszéd elindulásával világossá vált, hogy az ELTE gyüjteményeinek története és jelenlegi helyzete igen nagy hasonlóságot mutat a bécsi egyetemi gyüjteményekkel, habár a lépték más.

Jelen tanulmányomban tehát szeretném az ELTE kulturális javainak, a tudományos és oktató gyüjteményeinek alapítását, sorsát és jelenlegi helyzetét - a terjedelmi korlátokból kifolyólag vázlatosan és kiemeléseket alkalmazva - bemutatni, valamint összekapcsolni az egyetemtörténeti fordulópontokkal, nemzetközi kontextusba helyezve azokat. Célom rávilágítani arra, hogy az egyetemi örökség kérdése a történeti múlttal rendelkező egyetemeken jelen van, s igen nagy hasonlóságok mutathatók ki az egyetemi gyüjtemények sorsában; az intézményi sajátosságok figyelembevételével különböző stratégiákat dolgoztak ki az egyetemi gyüjtemények kezelésére és koordinációjára, amelyek az ELTE gyüjteményeinek esetében is alkalmazhatóak.

Annak érdekében, hogy az általam kiválasztott, az ELTE-n ma is megtalálható egyetemi gyüjteményeket, valamint az ezek számára lehetséges integrációs formákat nemzetközi kontextusban bemutathassam, két múzeumtörténeti modellt kell bevezetnem.

Marta C. Laurenco a doktori disszertációjában ${ }^{1}$ végzett nagy volumenü kutatása keretén belül a legtöbb európai egyetem történetének vizsgálata után állította fel azt az elméletet, hogy az egyetemi gyüjtemények és múzeumok történeti fejlődésük során hat típusba sorolhatóak létrejöttük szerint. Az első típus az ún. korai oktató és tanulmányi „gyüjtemény” (,,collection” of teaching and studying). Azért szükséges a gyüjtemény szót idézőjelbe tenni, mert az adott időszakban még nem beszélhetünk tervszerü gyüjtésröl, csupán arról van szó, hogy a különböző oktatási eszközök használata egyidős magával az oktatással, de ezek bekerülése az egyetemekre esetleges.

A második típus az ún. oktató gyüjtemény (teaching collection), amely a szemléltetésre kiállított tárgyakon alapuló oktatás és tanulmányozás fejlődésével vette kezdetét a középkori egyetemeken. Erre az első példák a 16. századtól kialakított hortus medicusok (a vizsgálat tárgyai a növények), az anatómiai színházak (a vizsgálat tárgya az ember), valamint a 18-19. században általánossá váló fizikai szertárak vagy kabinetek, amelyek számos esetben önálló múzeummá váltak a 20. század folyamán. Például 1928-ban így jött létre az utrechti Egyetemi Múzeum, 1938-ban pedig a coimbrai Fizikai Múzeum (Phsycs Museum, jelenleg a Science Museum of the University of Coimbra elnevezésü intézmény része) alakult meg.

1 LAURENCO (2005: 49-84). 
A természettudományok fejlődésével egyre inkább előtérbe került az első tanulmánygyüjtemények (study collections) létrehozásának igénye. Ezeknek a virágkora a 16-18. századra esik, kialakításuk általában egy-egy oktatóhoz kötődik, akiket személyes érdeklődés vagy szakmai cél vezetett; például számos osztályozási rendszer kialakításában segítettek ezek a gyüjtemények. Az első ilyen tanulmánygyüjteményt feltételezhetően Ulisse Aldrovandi (15271605), a bolognai egyetem fosszíliákat, növényeket és állatokat tanulmányozó professzora alakította ki.

A negyedik típusba sorolt kutatógyüjtemények (research collections) észrevétlenül alakultak ki a tanulmánygyüjteményekböl, elsősorban a 18-19. században, annak köszönhetően, hogy a professzorok érdeklődni kezdtek a természeti jelenségek mintáinak összegyüjtésén túl azok összehasonlítása és előállítása iránt is. Elsősorban az állattan, paleontológia, botanika, ásványtan, geológia, régészet, antropológia és a néprajz területén figyelhető meg a kutatógyüjtemények kialakulása.

Az ötödik típusba a müvészeti gyüjtemények (art collections) tartoznak. Az egyetemek tulajdonába már alapításuk során kerültek különböző mütárgyak. Ezek általában emléktárgyak, szakrális és ceremoniális tárgyak, portrék és freskók, kéziratok és könyvek. Azonban az így összegyült mütárgykincs nem nevezhetö - még akkor sem, ha több hasonló készült belölük - gyüjteménynek, amelynek feltétele valamilyen rendszer kialakítása. Az első müvészeti gyüjtemény feltételezhetően 1546-ban került kialakításra, amikor az oxfordi egyetemen található Christ Church College-ban megalapítottak egy festménygyüjteményt.

A hatodik típus pedig az ún. egyetemi múzeum (university museum), amelyeknek az alapfunkciója nem egyezik meg a jelenleg használt múzeumi alapfunkciókkal: elsődleges célja az egyetemi polgárok közössége és az egyetemi oktatás és kutatás támogatása azáltal, hogy az összegyüjtött tudás és tárgyak bemutatását, tanulmányozását és kutatási lehetőségeit biztosítja. Az első egyetemi múzeum a világon - amely ma is az egyik leghíresebb múzeumok között van - az 1683-ban alapított Ashmolean Museum.

A második modell, amit szeretnék a bevezetésben felvázolni, az egyetemi örökség kezelésének, az egyetemi múzeumok típusának időbeli változását mutatja be. Ebben a folyamatban Clercq² generációs szinteket határozott meg. Az ún. első generációs egyetemi múzeumok a 16. század végétől jelentek meg. Ezek a specifikus múzeumok általában téma-orientáltak voltak, szorosan kapcsolódtak az egyetemen folyó kutatáshoz és oktatáshoz, de feladatukul tűzték ki a nyilvános bemutatást is. Általában egy jól kialakított egyetem több mint húsz gyüjteménnyel rendelkezett.

2 ClercQ (2006: 23-30); ClercQ (2009: 13-21). 
Az ún. második generációs egyetemi múzeumokat a 20. század első felében hozták létre. Az addig felhalmozott, de múzeummá nem alakított gyüjteményekből elsősorban tudományos múzeumokat hoztak létre, melyeknek célja az elavult 18-19. századi eszközök, modellek és laboratóriumi felszerelése megörzése volt. Erre a típusra példa az Oxfordi Egyetem 1924-ben alakult Tudománytörténeti Múzeuma, vagy Leidenben az 1929-ben létrehozott Boerhaave Múzeum, amely azóta nemzeti múzeumi státuszt kapott és már nem csak az egyetemi közösséget szolgálja ki.

A 20. század második felében, elsősorban az 1980-as évektől kialakított egyetemi múzeumokban - hasonlóan a más indíttatásból létrejött múzeumokhoz - erőteljes szerepet kap a múzeumpedagógia, az identitásteremtés és a tudománynépszerüsítés. Ezek az intézmények, amennyiben elköteleződnek a nyilvánosság mellett, kaput jelenthetnek az egyetemen zajló kurrens kutatások széles körü terjesztésére.

\section{Az egyetemi gyüjtemények és kulturális javak helyzete, lehetőségei a kezdetektől napjainkig - vázlatos áttekintés}

Az Eötvös Loránd Tudományegyetem története egészen a 16. századig nyúlik vissza. Ebben az időszakban gyengült meg a katolikus egyház hatalma, a reformáció térnyerésével egész városok váltak protestánssá, ráadásul Magyarországon a törökök elleni harc és a katolikus klérus vezető tagjainak halála miatt további veszteségeket szenvedett a katolikus egyház fennhatósága. Buda 1541-es elfoglalása után a Magyar Királyság három részre szakadt, az ország vezető tisztségviselői és hivatalai a katolikus föpapokkal együtt a királyi Magyarország területére menekültek. Két szabad királyi város alakult át hatalmi központtá: Pozsonyban talált új otthonra az állami intézményrendszer, Nagyszombatban az esztergomi érsekség és káptalan 1543-tól. ${ }^{3}$

Az 1545-1563 között kisebb-nagyobb megszakításokkal ülésező tridenti zsinaton az egyik legfontosabb kérdés a reformáció elleni küzdelem és a katolikus megújulás kérdése volt. Ennek következtében került előtérbe az 1540ben katolikus szerzetesrendnek elismert Jézus Társaság. Tagjainak célkitűzése a kora újkori oktatási rendszer megismerése és az általuk feltárt pedagógiai problémákra reflektálva saját intézményrendszer kialakítása volt nemzetközi szinten, melynek alapját a Ratio Studiorumnak nevezett tanulmányi tervben fektették le. ${ }^{4}$

Magyarországon Oláh Miklós (1493-1568) érsek oktatásügyi reformjai révén kívánt új lendületet adni a papi képzésnek, a katolikus oktatásnak annak

3 MAdAS-MONOK (1998: 93-107).

4 Mikonya (2014: 303-304). 
érdekében, hogy az iskolából kikerülő papok képesek legyenek a hitvitákban logikusan érvelni és retorikai fogásokat alkalmazni. Ennek keretén belül Nagyszombatban 1554-ben hozta létre a káptalani-városi iskolát, melynek felügyeletét 1558-tól maga az érsek látta el. Továbbá Oláh Miklós hívta be 1561ben a királyi Magyarországra a Jézus Társaságot I. Ferdinánd engedélyével. A jezsuiták missziós tevékenységet végeztek az országban és elkezdték kiépíteni a már Európa-szerte alkalmazott oktatási módszereiket követő intézményeiket. A jezsuita kollégiumi rendszer keretén belül Magyarországon is alapítottak könyvtárakat, elsőként Nagyszombatban. ${ }^{5}$

Miután néhány évvel később az első nagyszombati kollégium és könyvtár leégett, Rudolf királytól kapta meg a rend a túróci prépostságot. Forgách Ferenc (1560-1615) érsek segítségével 1615-ben alapították újra a nagyszombati jezsuita kollégiumot. ${ }^{6}$ A mai Egyetemi Könyvtár jogelőd intézményeinek állományából számos kötetet ma is a muzeális értékü könyvállomány részeként őriz. A nagyszombati, túróci és vágsellyei jezsuita kollégiumok könyvanyagából számos 16. századi nyomtatványt tartalmaz az ún. Antikva gyüjtemény. A legrégebbi ősnyomtatvány pedig egy 1586-1589 között beszerzett, Cicero müveit tartalmazó kolligátum, amelyet a jezsuiták tankönyvként használtak az oktatásban. ${ }^{8}$ Az egyetem 1635-ös megalapításától kezdve a könyvtár története szorosan összekapcsolódik az egyetem történetével, a könyvgyarapítások pedig azóta is az egyetemen zajló oktatás támogatását szolgálják.

Pázmány Péter (1570-1637) jezsuita szerzetest 1616-ban nevezte ki esztergomi érsekké II. Mátyás. A rend által kialakított és Európában már müködő - például a mintaként vett grazi egyetem is ilyen - kétfakultásos egyetemtípust szerette volna Magyarországon is meghonosítani. Ennek megfelelően az alapképzést a bölcseleti fakultás elvégzése jelentette, amely a nemesek számára elegendő volt a világi pályák betöltéséhez. Ez a rendszer elöírta, hogy az egyházi pályaválasztáshoz kötelező teológiai karra csak a filozófiai stúdiumok elvégzése után lehetett beiratkozni. Az egyetem alapítására végül 1635-ben kerülhetett sor II. Ferdinánd támogatásával, ${ }^{9}$ ugyanis VIII. Orbán (1568-1644) pápa nem akarta jóváhagyni a hiányos szerkezetü egyetem létrehozását. ${ }^{10}$ Az intézmény fenntartásához szükséges alapítványi összeget (60 000 forint), valamint az alapítólevelet 1635. május 12-én adta át, megbízva ezzel a nagyszombati

\footnotetext{
5 FARKAS (2008: 7-10).

6 Sinkovits (2003: 16-17).

7 KNAPP-SZÖGI (2012: 152).

8 KNAPP-SzÖGI (2012: 95).

9 II. Ferdinánd császár egyetemalapítást megerősítő oklevele, 1635. október 18. ELTE Egyetemi Könyvtár és Levéltár, Egyetemi Levéltár. I/c-III. Rektori Hivatal iratai. Alapítólevelek.

10 FARKAS (2008: 23-24).
} 
jezsuitákat az uralkodó által elismert egyetem müködtetésével. Ebben lefektette az egyetemalapítás legfontosabb céljait: a katolikus vallás terjesztése és a magyar nemzet méltóságának emelése. ${ }^{11}$ Terveinek megfelelően a tanítás még ebben az évben megkezdődhetett, az ünnepélyes tanévnyitóra 1635. november 13-án került sor. ${ }^{12}$

A 17. század első felében számos más egyetemet is alapítanak az ellenreformáció jegyében. Ekkor élik virágkorukat az Ibériai-félszigeten található salamancai és coimbrai egyetem, valamint a magyar diákok körében kedvelt peregrinációs célpontok, mint Graz, Würzburg és Dillingen jezsuita egyetemei. A 16. század második felétől alapított jezsuita kollégiumokban és kvázi-egyetemeken kötött, igen szigorúan kialakított rend szerint haladhattak elöre a diákok a tanulmányaikban. A közös katolikus értékrend kialakítása és erősítése érdekében kötelező volt minden hallgató számára a latin nyelv ismerete, de a nem teológiai képzésben részt vevők számára olasz és német területeken engedélyezték a helyi nyelvek használatát is. ${ }^{13}$

Ezzel szemben más, középkori alapítású négyfakultásos egyetem, mint Pádua, Róma, vagy Párizs katolikus, illetve Leiden és Heidelberg kálvinista szemléletü intézményei a vallási toleranciát választották, és nyitva álltak más keresztény felekezethez tartozó hallgatók számára is. Ugyanis ezeken nem a teológiai képzés, hanem a másik három kar került előtérbe. A humanista és a teológiai szemléletủ egyetemeken túl létezett még a tudományos fokozatot ugyan nem adó, azonban az egyetemi képzésböl kiszorult speciális (természettudományos és technikai jellegü) ismeretek oktatását felvállaló akadémiák. Továbbá külön csoportot alkottak az angol college-rendszer felsőfokú képzést biztosító intézményei, amelyben az elnevezés a hallgatók kötelező lakóhelyére utal..$^{14}$

A VIII. Henrik által kezdeményezett reformáció lehetővé tette, hogy az oktatási intézmények ellenőrzésében megszünjön mind a világi, mind az egyházi (pápai) hatalomnak a kontinens egyetemein továbbra is megfigyelhető aktív befolyása. 1538-ban, a szerzetesrendek megszüntetésével egyidőben kialakult az új oktatási rendszer, melynek felügyeletét a király látta el. Jelentős, a világ első egyetemi múzeumát és Nagy-Britannia első közgyüjteményét alapította meg 1683-ban Elias Ashmole. Az oxfordi egyetemen létrehozott intézményben különböző, a szemléltető oktatást elösegítő gyüjtemény található, melyeknek

11 Pázmány Péter alapító oklevele, 1635. május 12. ELTE Egyetemi Könyvtár és Levéltár, Egyetemi Levéltár. I/c-III. Rektori Hivatal iratai. Alapítólevelek.

12 Sinkovits (2003: 16-17).

13 Mikonya (2014: 359-360).

14 Mikonya (2014: 309-311). 
alapját Ashmole saját gyűjteményei jelentették: herbáriumon, rovargyüjteményeken, szakkönyvtáron és pinakothékán túl természettudományos laboratóriumok is helyet kaptak a múzeumban. ${ }^{15}$

\section{Reprezentációs eszközök a kora újkori egyetemeken}

A szimbólumok, egyetemi címerek és különböző reprezentációs eszközök használata jelentős a különböző korszakokban alapított egyetemek ünnepi rituáléiban, ugyanis ezek utalnak az alapítás korára, az alapítás aktusára és - korai alapítások esetén - a folytonosságra.

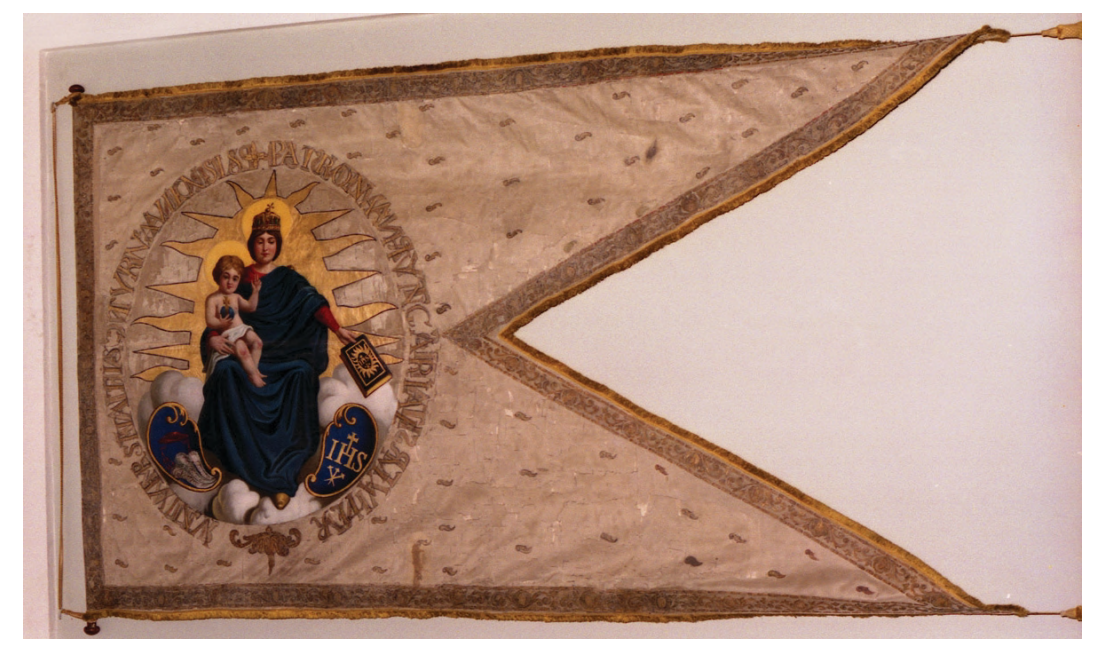

1. kép: Az egyetem első zászlója, 1635k. ELTE Aula Magna. Nagyné Pál Gabriella felvétele.

A középkori és kora újkori alapítású egyetemek a mai napig használják a korai alapításról tanúskodó szimbólumaikat, pecsétjeiket (például Bécs és Krakkó). Mivel Pázmány Péter nem adományozott saját címert az intézménynek, az ELTE-n nem ez történt, hanem az alapító címereit használták. Erre látványos példa az egyetem első zászlója, melyen nem csak a védőszentként szereplő Madonna (Patrona Hungariae) látható a gyermek Jézussal, hanem a Madonna jobb lábánál Pázmány Péter családi címerét is elhelyezték. ${ }^{16} \mathrm{Ke}-$ vésbé látványos példa, hiszen az eredeti pecsétnyomó elveszett, Maylád Mik-

15 Mikonya (2014: 320-321).

16 Az egyetem első zászlója, 1635k. ELTE Aula Magna. 
lós 1642-ben kiadott diplomájának pecsétnyomata, amely a védőszent Madonnát jobb kezében a Bibliával, bal kezében a gyermek Jézussal ábrázolja, míg a pecsétkép alatt kapott helyet Pázmány Péter bíborosi címere: három strucctoll a bíborosi kalap alatt. ${ }^{17}$ Az egyetem számára Mária Terézia adományozott címert (egyúttal nagypecsétet), melynek részletes leírása az 1780-ban, a Budára történő költöztetéssel egyidőben kiadott Diploma Inaugurale-ban olvasható. Ez alapján a szívpajzs - amely a mai napig használatban van - egy régebb óta használt, Zsigmond által az óbudai egyetemnek adományozott címer szimbólumára utal:

„az alsó pedig a budai főtanoda [egyetem] ősi jelvényét mutatván, úgymint kék mezőben ezüstsújtásos, aranyöltönyü s jobbra kinyújtott, arany szegély fekete táblába kötött zárt könyvet tartó kart..."18

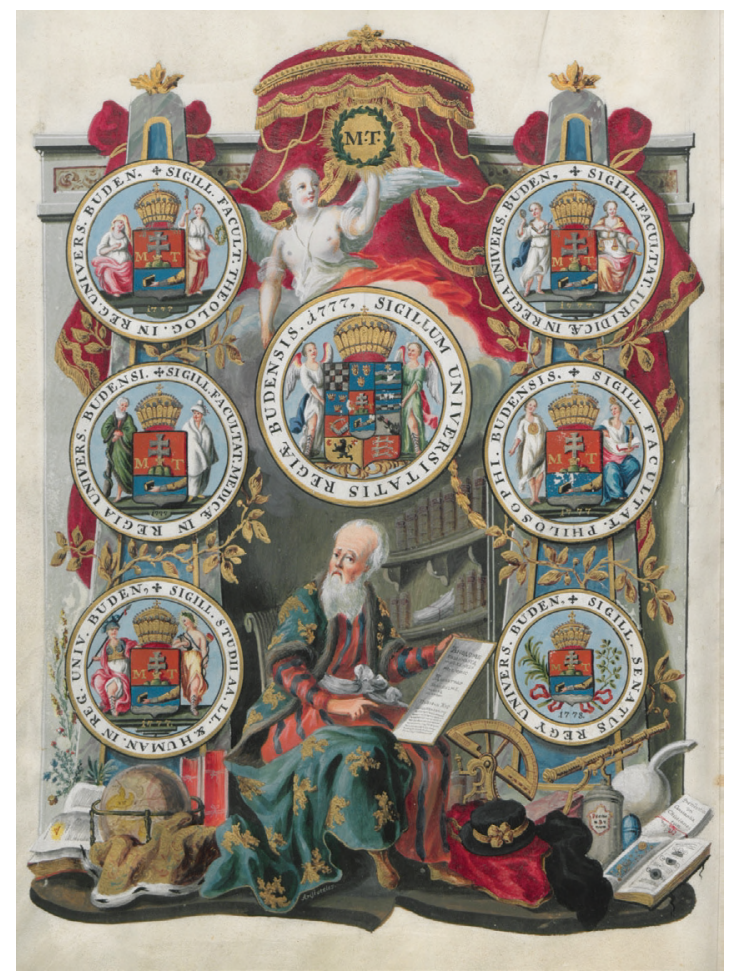

2. kép: Diploma Inaugurale, 1780. március 25.

ELTE Egyetemi Könyvtár és Levéltár, Egyetemi Levéltár

17 Majláth (1899: 144).

18 PAPP (1982: 79). 
Csakúgy, mint az egyházi és uralkodói oklevelek esetében, az egyetemeknek is szüksége volt saját, az autonómiát igazoló pecsétre, amellyel az általuk kiadott okmányokat hitelesítették. A pecsétek megbecsültségét mutatja, hogy például a duisburgi egyetem alapítására rendezett körmenetben az új egyetem pecsétjét egy díszpárnán hordozták körbe a menet elején 1654-ben. Ezen az ovális alakú pecséten az alapító II. Miksa portréja látható, de számos egyetem pecsétjén az egyetem védőszentje szerepel, például az ELTE által 1642-ben használt pecséten. ${ }^{19}$ Az ELTE korai rektori és kari pecsétjeit csak töredékesen ismerjük. A karok 1772-ben kaptak Mária Teréziától egységes pecséteket, de az intézmény Budára költözése miatt hamar új pecsétekre lett szükség. Az 1777-ben adományozott intézményi pecsét kifejezi az országos jelleget, ugyanis ahogy az a Diploma Inaugurale címerképén látható, a szívpajzsot a koronához tartozó országok címerein helyezték el, míg a királyi jelleget a szívpajzson elhelyezett korona hivatott kifejezni. Összesen 7 pecsét került adományozásra ekkor, ugyanis a négy karon kívül saját pecsétet kapott a szabad múvészetek fógimnáziuma és az Egyetemi Királyi Tanács (Senatus) is. Ezeken az intézményi pecséten is látható szívpajzsot más-más, az adott szervezeti egységre jellemző pajzstartó (telamon) fogja közre, míg a szenátus pecsétjét jobbról egy babér-, balról egy olajág fogja közre. ${ }^{20}$

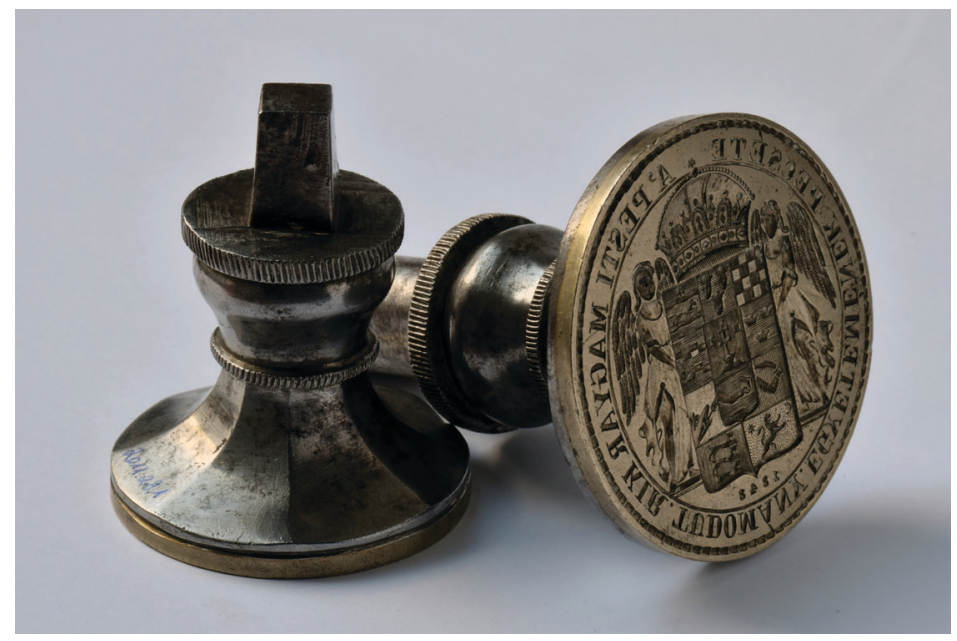

3. kép: Az egyetem nagypecsétje a Pestre költözés után. ELTE Egyetemi Könyvtár és Levéltár,

Egyetemi Levéltár. Egyetemtörténeti Gyüjtemény. Képessy Bence felvétele.

19 Mikonya (2014: 429).

20 Diploma Inaugurale, 1780. március 25. ELTE Egyetemi Könyvtár és Levéltár, Egyetemi Levéltár. I/c-III. Rektori Hivatal iratai. Alapítólevelek. 
Szintén az egyetemi autonómiát, egész pontosan a bíráskodás és a szabad doktoravatás jogát fejezi ki a jogar vagy díszbot, latin kifejezéssel a pedum vagy sceptrum. Az ELTE számára más jezsuita intézményekhez hasonlóan az alapítással egyidőben adományozott rektori és két dékáni pedumot Pázmány Péter; ezek használatáról a királyi megerősítő oklevél szól:

„Európa összes akadémiái által ilyeneknek tartassanak és magának a felavatásnak ténye által részesei legyenek mindazon kiváltságoknak, kegyeknek, mentességeknek, megbecsültségnek, kivételeknek, a melyeknek egyéb akadémiákon mások örvendenek, [...] akár ékességben, mint a milyenek a talárok, doctori süvegek, gyürük és az akadémia efajta jelvényei, a melyeket bárki rendfokának és hivatalának megfelelő jogarral, pecséttel és czímekkel együtt engedélyezettnek mondunk ki..."21

A rektori pedum tetején az intézmény védőszentje látható: Madonna a gyermek Jézussal. A szobor lábánál két pajzs (a később a pecséteken is használt Magyarország címerének négy folyója, valamint a hármas halomból kiemelkedő apostoli kereszt), míg a gomb tetején két vésett címer látható: a jogar feltételezhetően 1635 elött készült, ugyanis nem csak Pázmány Péter bíborosi címere, hanem a végül engedélyt nem adó VIII. Orbán pápa három méhet ábrázoló címere is helyet kapott. ${ }^{22}$ A bölcseleti fakultás egykori jogarán drágakövekkel díszített abroncsban Xavéri Szent Ferenc, a bölcsészek védőszentje látható. ${ }^{23}$ A teológiai kar peduma feltételezhetően nem készült el az alapításra, ugyanis az ünnepélyes megnyitón még a jogar nélkül vonultak fel. A díszbot gömbjét 1785-ig a kar védőszentjének, Szent Ignácnak a szobra díszítette. ${ }^{24}$ A megrongálódott jelvényt később látták el a Megváltó alakjával. ${ }^{25}$

Az egyetem további karokkal történő bővítése során új jogarokat is készítettek. Az 1667-ben alapított jogi kar is megkapta ugyanazokat a kiváltságokat, s az ekkor adományozott pedum tetején a kar védőszentjének, Szent Ivónak az alakja látható. ${ }^{26}$ A negyedik kar, az orvosi kar alapítására csak 1769-ben került sor, melynek dékánja a rákövetkező évben szintén megkapta saját hivatali jelvényét, melyen Szent Lukács látható az ökör attribútumával. ${ }^{27}$

21 PAPP (1982: 171).

22 Rektori pedum, 1635k. Magyar Nemzeti Múzeum Történeti Tár, Ötvösgyüjtemény. Ltsz. 1949.17.

23 Bölcsészettudományi Kar peduma, 1635k. Magyar Nemzeti Múzeum Történeti Tár, Ötvösgyüjtemény. Ltsz. 1949.20

24 PAPP (1982: 63).

25 Hittudományi Kar peduma, 1635k. Pázmány Péter Katolikus Egyetem Hittudományi Kar.

26 Állam- és Jogtudományi Kar peduma, 1667. Magyar Nemzeti Múzeum Történeti Tár, Ötvösgyüjtemény. Ltsz. 1949.19.

27 Orvostudományii Kar peduma, 1770. Semmelweis Egyetem, Rektori Hivatal. 
Hatalmi jelvényként jelent meg a kora újkor végén a rektori és dékáni láncok viselésének szokása, ugyanis a hasonló medállal ellátott, nemesfémből készült láncok korábban a fónemesek és a magas beosztású udvari hivatalnokok kiváltsága volt. A prágai egyetem rektora és dékánjai már a 16. század folyamán viselték a hivatali láncot, Bécsben pedig a 18. században váltja fel a hivatali lánc az addig viselt talárt. ${ }^{28}$ I. Ferenc a 19. század folyamán a birodalom többi egyetemének is adományozott hasonló tisztségláncot az 1806. évi II. Ratio Educationis kiadása után, a lembergi egyetem 1817-ben, a pesti egyetem 1819-ben (ünnepélyes átadására 1820. május 18-án került sor), 1826-ban az innsbrucki és a grazi egyetem, 1837-ben pedig az olmützi egyetem kapta meg új jelvényeit. Az ELTE láncait és a rajtuk elhelyezett, az adományozó - a bécsi befolyás és abszolutizmus kifejezésére - I. Ferenc portréjával ellátott medálokat aranyból készítette a bécsi Johann Baptist Harnisch. ${ }^{29}$

A II. világháborút követő politikai átalakulás a felsőoktatási intézményeket is érintette. 1948. június 16-án elfogadták az iskolák államosításáról szóló törvényt, majd az egyetemi reform elemeinek kidolgozása következett. 1947. márciusában a kisgazdapárti, 1946 óta egyetemi tanárként dolgozó Ortutay Gyula került a vallás- és közoktatásügyi miniszteri pozícióba. Az általa végrehajtott reform célja az egyetemi autonómia teljes megszüntetése, az egyetemeken folyó oktatás pártállami ellenőrzése volt, $\mathrm{s}$ hogy a föiskolák müködését összehangba hozzák a megváltozott, megváltoztatott társadalmi és müvelődéspolitikai igényekkel. Az 1948/49. évi tanév jelentette a fordulatot a magyar felsőoktatásban, 1949 nyarától megszűnt minden jellegü egyetemi autonómia. ${ }^{30}$

A fentebb említett, adományozás révén kapott, az egyetemi autonómiát kifejező és biztosító tisztségjelvényeket is ekkor vették el az ELTE-től. Mivel a Vallás- és Közoktatásügyi Minisztérium kérésére az Egyetemi Tanács nem volt hajlandó átformálni a pedumokat és láncokat - arra hivatkozva, hogy ezek zárt egységet alkotó, mủemlék jellegü relikviák az alapítás korából -, ehelyett használatukat felfüggesztve múzeumi megőrzést javasoltak. Az aranyból készült tisztségláncokat és a nemesfémböl készült, drágakövekkel díszített jogarokat 1949. május 31-én helyezték el a Magyar Nemzeti Múzeumban; több más festmény és szobor is eltávolításra került ekkor.

Mivel 1951-ben az MDP eltörölte az egyetemek doktoricím-adományozási előjogát, valamint a rektori és dékáni szabad választást, így a tisztségjelvények is ceremoniális funkciójukat vesztették rövid időre. Az egyetem számára leg-

28 Mikonya (2014: 429-430).

29 Bölcsészettudományi Kar dékáni lánca, 1819. Magyar Nemzeti Múzeum Történeti Tár, Ötvösgyüjtemény. Ltsz. 19.I.12./1949.

30 BoRSODI (2003: 314-321). 
közelebb csak a 325. jubileumra készítettek új tisztségjelvényeket. 1957-ben visszaállították a doktorátust, és újra elrendelték az avatással egybekötött ceremóniák megtartását. Az Egyetemi Tanács, Ortutay Gyula rektori kezdeményezésére, 1958-ban hozott határozatot az új pedumok és láncok elkészíttetésére. Az Iparművészeti Vállalat Eötvös Stúdiójában 1960 májusára készültek el az új rektori, jogi kari, bölcsészettudományi kari, és az alig 10 éve létrehozott természettudományi kari tisztségjelvények. A politikai háttér megjelent a pedumok ornamentikájában is: levelekké stilizált ötágú csillagdíszek kerültek kialakításra. $^{31}$

Az újabb alapítású egyetemek annak érdekében, hogy saját identitásukat erősítsék és tekintélyüket hasonlóvá tegyék a korábbi alapítású intézményekéhez, általában szintén felveszik a ceremoniális szokásokat és a tárgyi kultúrát. ${ }^{32}$ Hasonló jelenség figyelhető meg az ELTE-n is az újabb karok alapításakor, az intézményhez csatoláskor. Ahogy a 17. században a jogi, a 18. században az orvosi, és 1960-ban az eredeti alapításkor még nem létező természettudományi kar is kapott saját tisztségjelvényeket, úgy a rendszerváltás után az egyetemi hálózat integrálásának során 2000-től az ELTE részévé vált a Bárczi Gusztáv Gyógypedagógiai Főiskolai Kar, valamint a Tanító- és Óvóképző Főiskolai Kar is kapott saját jelvényeket. Az ELTE ma is fennálló szerkezete 2003-ban alakult ki, amikor a már müködő öt kara mellé megalakult az Informatikai Kar, a Pedagógiai és Pszichológiai Kar, továbbá a Társadalomtudományi Kar. ${ }^{33}$

\section{Az elsö tanitást segitő gyüjtemények: a botanikus kertek}

Az egyetemi gyüjtemények első szervezett formái a botanikus kertek vagy füvészkertek voltak. A hortus medicus vagy orvosságos kert, melynek kialakításában része volt a tudomány és a hasznosság mellett az esztétikumnak is, a korai modern időkben jelent meg. Míg gyógynövényeket már az ókortól kezdve termesztettek és használtak a gyógyításban, az első kerteket, amelyek szerepet kaptak az egyetemeken folyó botanikai oktatásban is, a 15-16. században alapították. A füvészkertek jellegükből adódóan szorosan összekapcsolódtak egy egyetem orvosi karának tevékenységeivel, az azon folyó oktatást és kutatást segítették. Az első botanikus kertek itáliai egyetemeken alakultak,

31 PAPP (1982: 17-18; 65-70).

32 Mikonya(2014: 429-430).

33 Jelenleg ceremoniális eseményeken az 1960-as években, valamint az azóta készült tisztségjelvények vannak használatban, ezeket a Rektori Kabinetben örzik. 
például 1533-ban Páduában ${ }^{34}$ és 1544-ben Pisában, de hamar megjelentek más európai egyetemeken is, például 1587-ben Leidenben és 1593-ben Montpellierben. A páduai és leideni füvészkert különleges helyzetben volt, hiszen előbbi esetében Velence közelsége, a második esetében pedig a Holland Kelet-indiai Társaság révén számos egzotikus növényhez juthattak hozzá. ${ }^{35}$

Hamarosan 120 éves lesz az ELTE füvészkertje: alapítására 1771-ben, nem sokkal az egyetem orvosi karának létrehozása után került sor. Az egyetem 1771. július 18-án kapta meg Mária Terézia engedélyét arra vonatkozóan, hogy a város falain kívül eső területet vásárolhat hortus botanicus létesítése céljából. Azonban a megvásárolható telek nem volt alkalmas füvészkert létrehozására. Helyette 1774-ben, az egy évvel korábban feloszlatott Jézus Társaság telkeiből tudtak vásárolni alkalmas területet, de a beültetése váratott magára. Winterl Jakab, aki a kar alapítása óta szorgalmazta az oktatásban hasznosítható botanikus kert létrehozását, így érvelt a hortus botanicus késleltetett kialakításának következményeire utalva:

\begin{abstract}
Ám nem hiszem, hogy ne következnék el az idő, amikor az egyetem vezetöi is be fogják látni a botanikus kert szükségességét. A jogtudósok szerint a büntett az igazság anyja; a gyógyszerek körül elkövetett hibák majd Magyarországon is belátásra fogják bírni az embereket, hogy a botanikáról komolyabban kell gondolkodni. Akkor az orvosok is nagyobb bizalommal és biztossággal fogják gyakorolhatni praxisukat. ${ }^{36}$
\end{abstract}

A füvészkertet az egyetem Budára, majd Pestre költözésével szintén áttelepítették. Elöször Krisztinavárosban, az Angolkisasszonyok korábbi majorját nevezték ki az új területnek, majd 1783-ban a ferenciek telkén álló gyümölcsösbe került. 1809-ben költöztették át a mai Múzeum körútra, területe körülbelül a mai Trefort-kert helyén volt. Azonban az árvíz 1838-ban súlyosan megrongálta a területet. József nádor 1847-re megvásárolta az Üllői úti Festetich-parkot az Egyetem számára, így ide helyezték át az egyetemi botanikus kertet. Tehát vásárlás útján kapta meg az egyetem a legrégebbinek számító épületét: az egykori Festetich-parkban álló egyemeletes vadászkastély 1802-1803-ban épült (4. kép).

34 A padovai botanikus kert mint a világ első egyetemi botanikus kertje felkerült az UNESCO világörökségi listára. https://whc.unesco.org/en/list/824/, 2019. 12. 10.

35 SPenCER-Cross (2014: 56-57).

36 GYŐRY (1936: 60-61). Winterl leírása egyébként igaz a kórházak, klinikák kialakítására is; panaszában a hullák, betegek, orvosi eszközök hiányát is megemlítette. A füvészkert ügyéhez hasonlóan sikerült jól érvelnie, ugyanis Mária Terézia a német egyetemeket is megelőzve a tudományegyetem számára engedélyezte a nagyszombati városi kórházban való tanítást, az intézmény Budára költözésekor pedig már saját klinikát alakíthatott ki az intézmény. PAPP (1982: 103). 


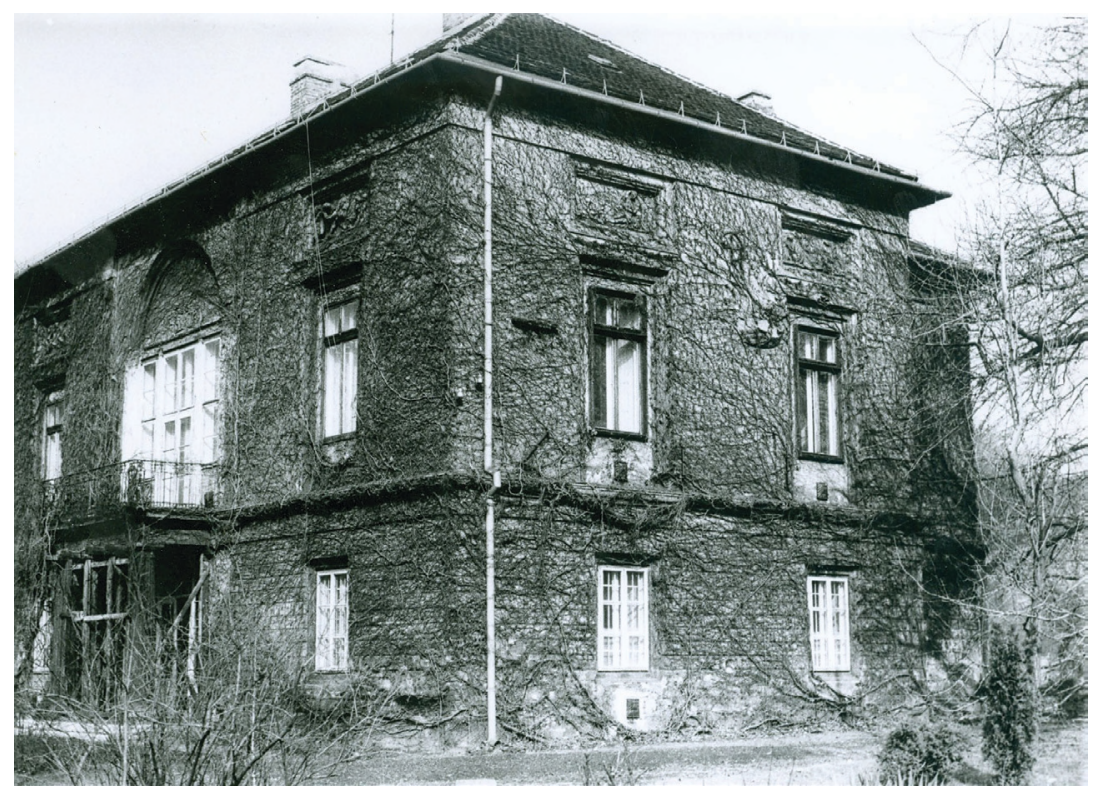

4. kép: A botanikus kert föépülete,

ELTE Egyetemi Könyvtár és Levéltár, Egyetemi Levéltár.

Egyetemtörténeti Gyüjtemény, 2008.239.1.

A botanikus kert eredetileg 10 hektár volt, azonban a 19. század végén szükség volt újabb épületekre a Trefort-kert szükössége miatt, így a területét jelentősen lecsökkentették (ma 3,1 hektár) és hamarosan magas épületeket húztak fel az orvosi kar klinikái számára a növények helyén:

Valamikor fiatal korunkban az Üllöi-út végén lévő nagy botanikus kertben készültünk csendben, szorgalmasan kollokviumainkra, tanári vizsgáinkra és hazánk nem egy nagy embere itt gyüjtötte alapismereteit. Azonban az orvosi tudomány fejlődésével szükség volt a helyre, a Botanikus kertet, a sciencia amabilis gyönyörü kertjét széjjelbontották, a mai tudományos kert a réginek talán egyötöd része. Minden kultúra világvárosnak büszkesége a Botanikus kertje, csak mi budapestiek nélkülözzük ezt már évtizedek óta. Egyetemi hallgatóinknak ma egyetlen kis pihenője a Múzeum körúti kis kert, ahol Trefort Ágoston szobra áll. ${ }^{37}$

37 PAPP (1982: 104-107). 
Tanulmánygyüjtemények, kutatógyüjtemények

Ahogy arról már volt szó a botanikus kertek tekintetében, Mária Terézia és II. József igyekezett színvonalas oktatási és tanulmánygyüjteményeket biztosítani az egyetem számára, de ennek ellenére nem tartozott Európa legkorszerübb intézményei közé, ráadásul folyamatos hanyatlás figyelhető meg. A bécsi udvar abszolutizmusának köszönhetően a 19. század első felében az udvar provinciális egyetemnek tekintette a magyarországi intézményt, csakúgy, mint más tartományi egyetemek. Jelentős támogatást a bécsi felsőoktatási intézmények kapták, azokon kívül pedig csak a prágai egyetem és polytechnikum kapott viszonylag nagyobb támogatást a fejlesztésre. Ennek következtében az épületek állapota leromlott.

A gyüjtemények tekintetében is hasonló figyelhető meg. Az egyetem természettani gyüjteménye csupán elfogadható volt, hiszen kisebb vásárlások s adományozások történtek - például 1809-ben Alexandra Pavlovna (17831801), József nádor felesége ajánlotta fel gyüjteményét -, de azok nem kellő mértékben tudták gyarapítani az egyetemi gyüjteményeket. A természettani (fizikai-mechanikai) és mérnöki-vízmütani gyüjtemények viszont alig követték a korszak technikai-tudományos fejlődését. Jedlik Ányos saját erőből gyarapította a gyüjteménytárat a színvonal fenntartása érdekében, ugyanis míg a fizikai eszközök beszerzésére Bécsben évi 1100 Ft állt rendelkezésre, addig Pesten csak 100 Ft jutott beszerzésekre.

Az 1848-49-es szabadságharcot követö önkényuralmi időszakban a humboldti modellt vették át, vagyis Leo von Thun-Hohenstein (1811-1888) az egyetemi reformjaival arra törekedett, hogy tudományos képzést biztosítson a magyar egyetemen is, lehetőleg szemléltető oktatással. Ehhez azonban szükség volt a megfelelő gyüjtemények, múzeumok és laboratóriumok biztosítására. Továbbá fontos változás a korszakban, hogy a bölcsészeti kar elökészítő jellege megszünt, legfontosabb feladatává ekkor a gimnáziumi tanárképzés megszervezése vált. Emellett cél volt, hogy a bölcsészeti képzést is arra a tudományos szintre emeljék, mint a gyakorlati szakmákat nyújtó jogi és orvosi karokat.

Az orvosi kar Pesten sokáig nem megfelelő körülmények között, a szükségesnél jóval kisebb épületekben volt elhelyezve. Thun-Hohenstein nagyszabású tervei nem valósulhattak meg pénzügyi okokból, csak 1859-ben tudta az egyetem megvásárolni az Állatgyógyintézet részére a város beépítés alatt álló kültelkének számító Ország út mellett (ma Múzeum körút) mellett álló Kunewalder-házat, de a korszerủ igényektől ez még messze állt. Másfelöl pedig, annak érdekében, hogy a bölcsészeti kar tudományos színvonala fejlődni tudjon, megfelelö helyszínre volt szükség a különböző gyüjtemények elhelyezésére és laboratóriumok kialakítására. ${ }^{38}$

38 SASHEGYi (2003: 193-196). 
A Pestre költöztetett tudományegyetem, amely más felsőoktatási intézmények, például a József nádor Mủszaki Egyetem 1872-es alapításával (magával vitte a mérnöki-vízmütani gyüjteményt) immár megkülönböztetésként a pesti, illetve az 1873-es egyesítés után a budapesti tudományegyetem elnevezést kapta. A hallgatók számának intenzív növekedésével, valamint a magyar tudományos képzés és a nyugati tudományos képzőhelyek színvonalához történő felzárkózás igénye elvárta, hogy a régi, az egyetem számára kiutalt városi épületek helyett kimondottan az egyetemi oktatás és kutatás számára tervezett épületek készüljenek. A 19. század folyamán, föként a század második felében, nagyarányú építkezések kezdődtek meg - az egyetemek felügyeletét az 1867es kiegyezés után ellátó - vallás- és közoktatásügyi minisztérium javaslatára és támogatásával. Az orvosi kar korszerü klinikai épületeiről volt már a fentiekben szó, a továbbiakban pedig két, a mai Trefort-kertben található épületet és az abban elhelyezett gyüjteményeket szeretném bemutatni.

A jelenleg Trefort-kertnek nevezett campus kiépítése a kiegyezés után kezdődhetett meg egy pesti/budapesti természettudományos képzési központ kiépítése érdekében. A kivitelezés jelentős része, valamint számos bővítés Trefort Ágoston (1817-1888) nevéhez köthető; az egyetem gyors növekedése következtében az Egyetem téri épületből folyamatosan költöztek el a bölcsészkar (ekkor még természettudományost képzést is nyújtó) tanszékei. Számukra - az orvosi kar és a Müegyetem tanszékeivel együtt - az egykori Füvészkert helyén, a Múzeum körúton álló kisebb telkek összevonásával húzták fel az új épületeket. ${ }^{39}$

Elsőként a „B” épületet adták át a Kémiai Intézet számára 1868-1871-ben. A szimmetrikus föhomlokzatú, közép- és sarokrizalitokkal, bejárati portikuszszal kialakított épületben 300 fős nagyelőadó, bal szárnyában kísérleti termek, jobb szárnyában raktárak, szertárak és az intézeti személyzet kapott helyet. A megfelelően kialakított laboratóriumok érdekében Than Károly (1834-1908) kémikus, az egyetem professzora tizennégy európai egyetemet látogatott meg annak érdekében, hogy a legkorszerübb mintákat láthassa ${ }^{40}$ Ezt a gyakorlatot a többi épület megtervezése előtt is folytatták. 


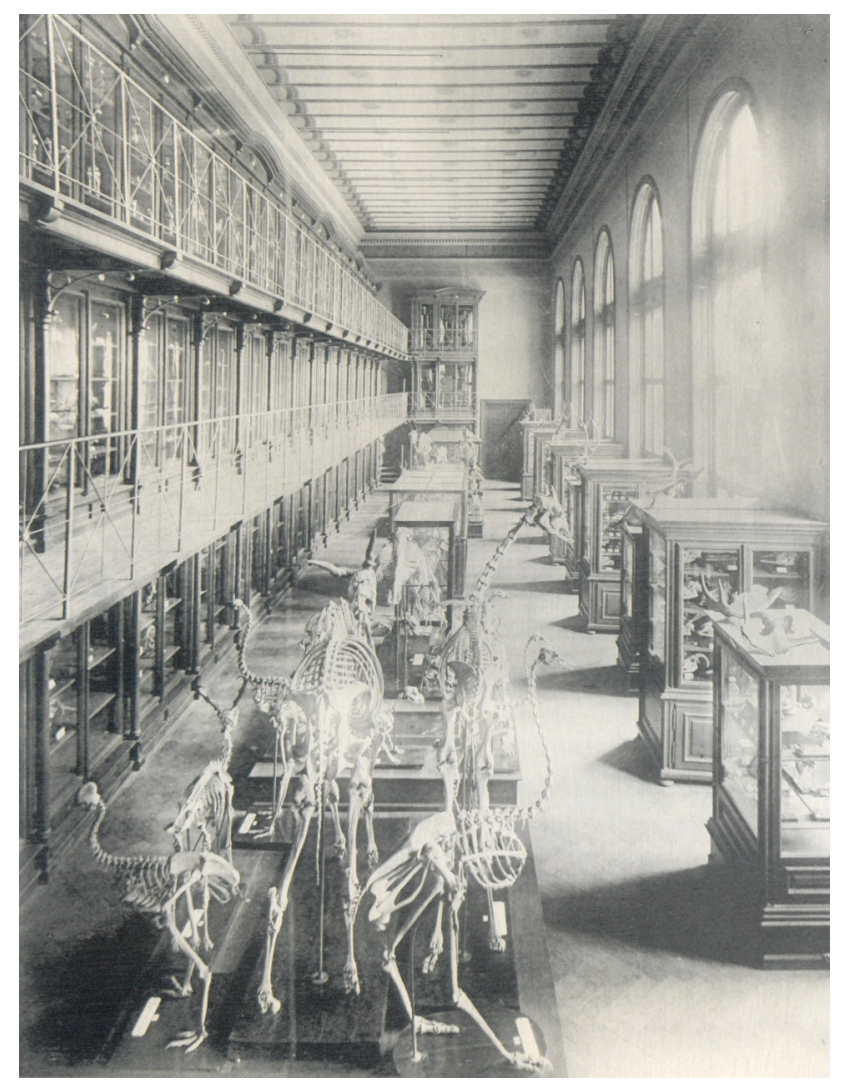

5. kép: Múzeum a Trefort-kertben. Királyi Magyar Tudományegyetem épületei,

1. kötet. Divald Károly fotója.

Az „A” épület eklektikus neoreneszánsz stílusú épülete 1883-1886-ban készült el, az orvosi kar és a bölcsészeti kar természetrajzi tanszékeinek (például állattan, növénytan, ásványtan, antropológia, paleontológia) adott otthont. Ezekhez múzeumok is csatlakozta, a szemléltető oktatás kiszolgálása mellett vasárnaponként a nagyközönség is látogathatta őket. ${ }^{41}$ Ezek közül a paleontológiai gyűjtemény alapítása az őslénytani tanszék felállításáig nyúlik vissza, 1882-ig, sorsa mind az egyetem, mind a tanszék aktuális helyzetéve összefüggött. Gyarapítása a kezdeti időszakban támogatott volt, elsősorban a természetrajz-tanárok vették hasznát, de ahogy azt a korabeli neve - Zoológiai és Összehasonlító Boncztani Múzeum - is kifejezi, összehasonlító kutatásokat is végeztek benne.

41 PAPP (1982: 117). 
Fennállásának több mint 130 évében a gyüjteményt kilencszer kellett átköltöztetni, gyakran a léte is veszélybe került rongálás, háborús károk, vagy a tanszék megszüntetése miatt. ${ }^{42}$

A természetrajzi épülethez tartozó gyüjtemények nagy része a második világháborúban elpusztult, Budapest ostroma alatt az egyetem épületei súlyos károkat szenvedtek. A 87 egyetemi épület nagy részének sérült vagy leomlott a tetöszerkezete és szinte az összes ablak betört, amelyek az épületek felszerelésében és a bennük elhelyezett gyüjteményekben is nagy kárt okoztak. Például a már említett 1809-es adományozású Pavlovna-féle kőzetgyüjteményből már csak az eredeti orosz nyelvü katalógus maradt meg. ${ }^{43}$

A világháborús károk enyhítése után a megmaradt gyüjteményeket tovább fejlesztették, a paleontológiai gyüjteményt az immár önálló természettudományi karon folyó geológusképzés szolgálatába állították, és az 1970-es évektől ismét jelentősen gyarapították. A kar új campusa 1998 és 2001 között átadásra került Lágymányoson, s 2002-től az északi tömb üvegpiramisában helyett kapott a természetrajzi gyüjtemények között a Biológiai és Paleontológiai Gyüjtemény is.

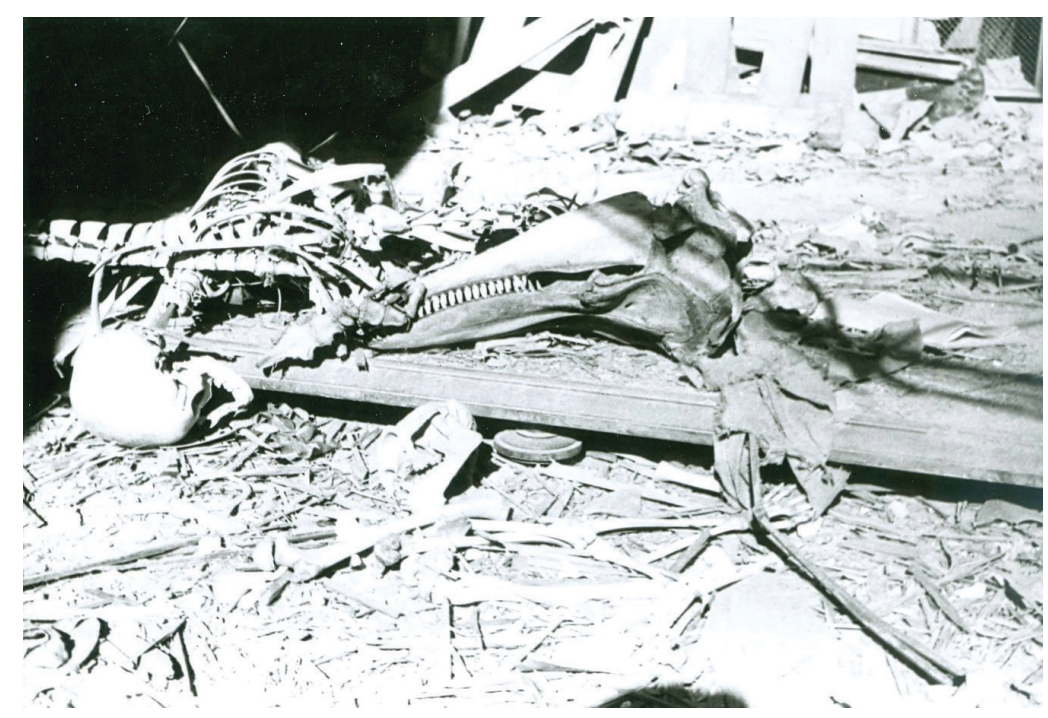

6. kép: A múzeum háború utáni romos állapota. ELTE Egyetemi Könyvtár és Levéltár,

Egyetemi Levéltár. Egyetemtörténeti Gyüjtemény, 2008. 258. 3.

42 Szeitz (2013: 383).

43 Borsodi (2003: 305). 
Visszakanyarodva a Trefort-kert 19. századi állapotához, a „D” épület átadására 1884-1886-ban került sor a fizikai intézet számára. Tervezésében Than Károly közremüködése mellett - Eötvös Loránd (1848-1919) egyetemi tanár is részt vett. Eötvös 1870-ben doktorált fizikából a heidelbergi egyetemen, 1871-től meg már a pesti tudományegyetem helyettes tanára, matematikai fizikaelőadásokat tartott. Rendes tanári kinevezését 1872-ben kapja meg az ekkor létrehozott elméleti fizika tanszéken, valamint az 1848-ban megszüntetett csillagászati tanszéket is ekkor létesítik újra. A másik fizikai tanszék, a kísérleti fizika rendes tanára ekkor Jedlik Ányos volt. Önálló fizikai épület hiányában Jedlik az Egyetem téri föépületben, Eötvös pedig a Than Károly által a rendelkezésére bocsátott előadóteremben tartotta meg előadásait. 1878-ban, Jedlik Ányos (1800-1895) nyugdíjba vonulásával Eötvös felügyelete alatt egyesült az elméleti és kísérleti fizikai tanszék (kísérleti fizika néven), ekkor kapta meg a Jedlik által kialakított (korabeli elnevezésével) természet-és erömütani gyüjteménytárat is, mely hamarosan otthonra is talált. ${ }^{44}$

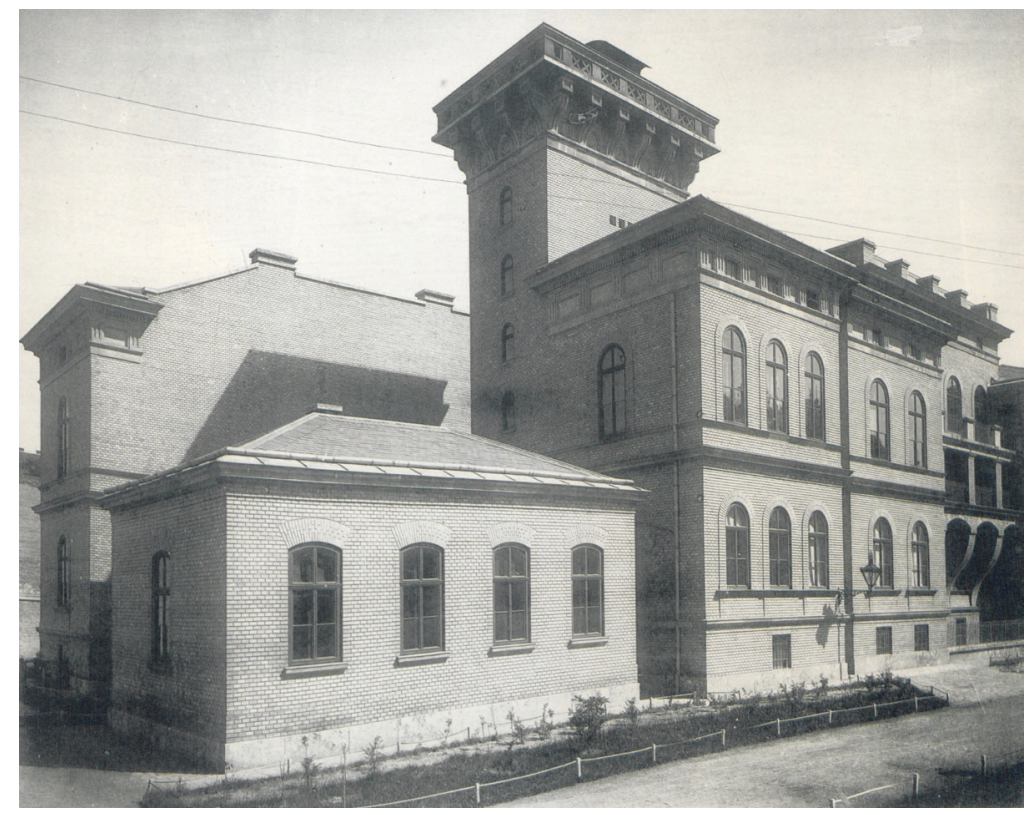

7. kép: A Trefort-kert D épülete. Előtérben a pavilon és a torony, háttérben a főépület homlokzata és a szertás épületszárnya. Királyi Magyar Tudományegyetem épületei, 1. kötet. Divald Károly fotója.

44 Buday-BudAYNÉ (1986: 106-134). 
Az 1886-ban átadott, eklektikus neoreneszánsz stílusú, nyerstégla-burkolatú épület amellett, hogy megfelelt a pontos és változatos fizikai mérések lebonyolításához szükséges követelményeknek, az Eötvös-család otthona is lett életük végéig. Az épület eredetileg 3 különálló részből állt. Az épületegyüttes legnagyobb része a fóépület, mellette két melléképület, egy földszintes pavilon és egy emeletes, toronnyal ellátott kisebb épületrész került elhelyezésre.

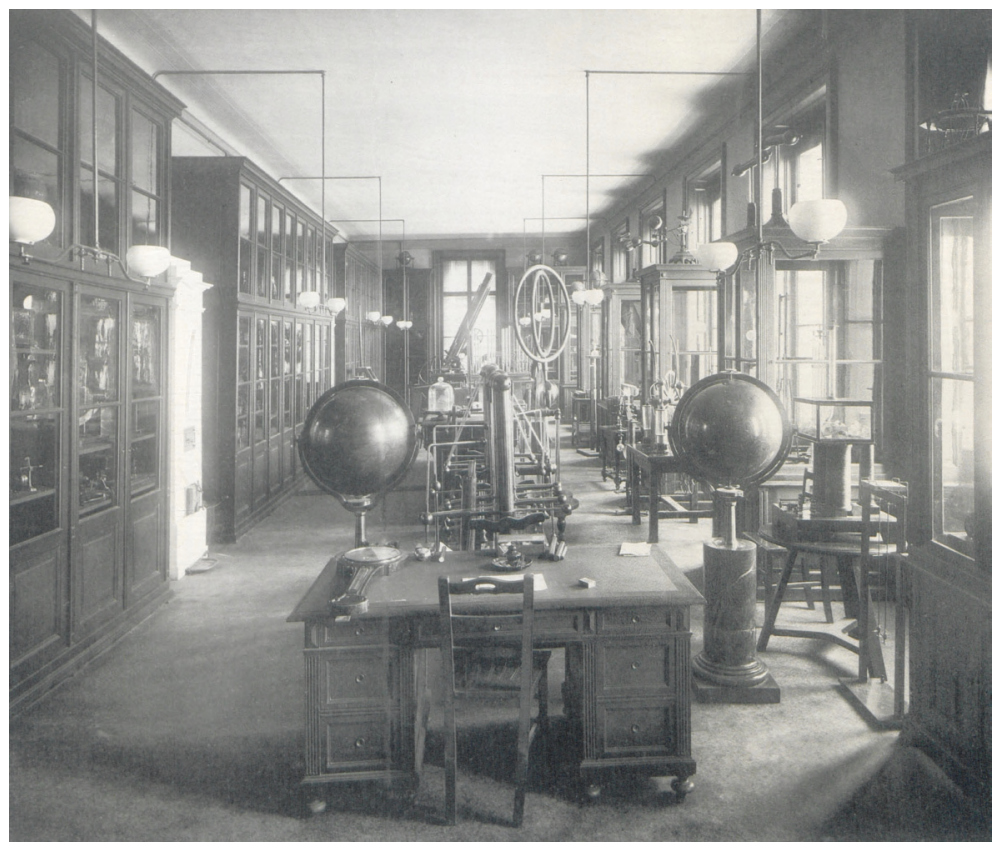

8. kép: A Fizikai Intézet új épületének demonstrációs szertára 1900-ban.

A Trefort-kert D épülete. Királyi Magyar Tudományegyetem épületei, 1. kötet. Divald Károly fotója.

A főépület első emeletén impozáns, kétszintes, lépcsőzetes kialakítású nagy előadóterem került elhelyezésre, melyet a hallgatók, az oktatók és a látogatók részére különböző ajtókkal láttak el. Körülbelül 250 ember fér el benne. A jelenleg táblaként használt nagy ajtó mögött voltak az előkészítő laboratóriumok. Ebből az elökészítő teremből lehetett a nagy ajtón keresztül átvinni az előadásokra a megfelelő müszereket. A kertbe keskenyen benyúló bal oldali szárnyban a kísérleti oktatás során használt tanszergyüjteményt, ${ }^{45}$ valamint Eötvös és

45 Az elsősorban 19. század folyamán gyártott demonstrációs eszközök között ugyanúgy vannak Heidelbergben vagy Párizsban gyártott eszközök, mint a magyar Calderoni által készített általános oktatási vagy egyedi megrendelésre készült eszközök. 
az egyetem egykori kutatóinak müszereit tárolták. Ezekből számos még ma is használatban van az Anyagfizikai Tanszék demonstrációs laboratóriumában, köztük számos innovatív, nemzetközi technikatörténeti szempontból jelentős eszközt is itt öriznek. Ugyanis Eötvös Loránd 1907-től tovább bővítette a „D” épület profilját. Már nem csak családjának és az egyetem Fizikai Intézetének adott otthont az épület, hanem itt alapította meg a Geofizikai Intézetet is. Az 1880-as évektől folytatott gravitációs mérések során kifejlesztett egy olyan eszközt, amely a föld alatt található nyersanyagok felkutatására alkalmas. A ma Eötvös-ingaként ismert eszköz lehetővé tette, hogy szerte a világban elinduljon az ipari szintű kőolaj-kitermelés. Eötvös a kutatási eszközeit szintén szertárában helyezte el.

A föépület mellett elhelyezett földszintes pavilon vasmentes szobái lehetővé tették a pontos mágneses méréseket. A mára betoldással összekötött emeletes melléképületben pedig háromablakos, kísérletekhez használt szobák kaptak helyet, illetve ebben az épületrészben található egy jelenleg lezárt, magasra felvezetett lépcső, melynek határoló falai négyszögletes, szigetelt tornyot képeznek. Gyakorlati jelentőségét Fröhlich Izidor (1852-1931), az elméleti fizika rendes tanára 1896-ban így foglalta össze:

„Ennek lapos kőkerítéses teteje csillagászati megfigyelésekre szolgál és széttolható faházat visz, melyen belől csillagászati eszközök vannak elhelyezve; ellenben nagy mélységü lépcsőháza nagy esés-magasságú kísérletek megejtésére és igen hosszú ingák lengésére alkalmas." ${ }^{" 46}$

\section{Más intézményekben alapitott, jelenleg az ELTE-hez tartozó gyüjtemények}

A 2000-es évek környékén történt integrációs folyamatoknak köszönhetően jelenleg az ELTE-n számos olyan gyüjtemény található, amelynek alapítása nem köthető közvetlenül az egyetemhez, bár a tudományos kapcsolódási pontok sok esetben tetten érhetök.

Az ELTE Bárczi Gusztáv Gyógypedagógiai Kar Gyógypedagógia-történeti Gyüjteményének gondolata a névadó, Bárczi Gusztáv (1890-1964) nevéhez köthető (kapcsolódási pont, hogy Bárczi a tudományegyetemen Eötvös Lorándtól hallgatott bevezető fizikai előadást a többi orvostanhallgatóval együtt, erről a gyüjteményben elhelyezett indexe is tanúskodik). Már 1944-ben felvetette az ötletet, hogy szükség lenne egy olyan történeti gyüjtemény felállítására, amely lehetővé teszi, hogy a gyógypedagógia 18. századra visszanyúló

46 HöGYES (1896: 486). 
múltját tanulmányozni lehessen, az elavult eszközök pedig így elhelyezésre és megőrzésre kerüljenek. A gyüjteményt 1965-ben alapították meg a Bárczi Gusztáv Gyógypedagógiai Tanárképző Főiskolán. ${ }^{47}$

Gothard Jenő (1857-1909) szombathelyi nemesi családból származott, a családjától a természettudományok iránti szeretetet és érdeklődést hozta magával. Nemesi származása ellenére Bécsben gépészmérnöki tanulmányokat folytatott, 1879-es hazatérés után azonban gazdálkodni kezdett, szabadidejében, a birtokán alapított Herényi Mücsarnokban kezdett kísérletezésbe és különböző müszerek gyártásába öccsével együtt. A csillagászat iránti érdeklődése Konkoly-Thege Miklósnak (1842-1916) köszönhető, aki 1871-ben meghívta Ógyallán alapított magánobszervatóriumába. Ennek hatására építtette meg Gothard Jenő és testvére, Sándor kastélyuk mellett a Herényi astrophysikai Observatoriumot, valamint hoztak létre egy modern asztrofizikai müszerparkot és szakkönyvtárat.

Haláluk után a szombathelyi premontrei gimnáziumnak és magánkezdeményezéseknek, 1957 után pedig a Városi Tanácsnak köszönhetően maradt meg és fejlődött tovább a csillagvizsgáló. 1972-ben került átadásra az új, igen korszerü csillagászati kupola. 1979-től a Gothard Asztrofizikai Obszervatórium az ELTE TTK Csillagászati Tanszékének gyakorlóhelyeként müködik közre az oktatásban és kutatásban. ${ }^{48}$

Egyetemi múzeumok lehetőségei és az egyetemi gyüjtemények koordinációs stratégiái - külföldi példák

Az ELTE-n már a különböző karok és tanszékek alapítása óta léteztek egyetemi gyüjtemények, és az egyetem vezetése a 20. század elején, 1911-ben határozta el először, hogy szükség lenne egy egyetemi múzeumra. Békefi Remig (1858-1924) bölcsészkari dékán az alábbi javaslatot tette a tanácsülésen:

Úgy látjuk és tudjuk, hogy egyetemünk múltjának szemléletes emlékei nagy részben elpusztultak. De mégsem minden. Van még sok menteni való. Most a tizenkettedik órában lássunk munkához, s még sokat pótolhatunk. S éppen most kedvező alkalom kínálkozik, hogy egy szobát a megalapítandó Tudományegyetemi Múzeum részére biztosítsunk. Ez a Múzeum örizné mindazokat a tárgyakat, melyeket a kegyelet egyetemünk emlékei közé sorol. Ide tartoznak egyetemünk legrégebbi és tartalmilag nagyfontosságú oklevelei, pecsétei, anya-

47 ELTE Bárczi Gusztáv Gyógypedagógiai Kar Gyógypedagógia-történeti Gyüjtemény https://barczi. elte.hu/content/gyogypedagogia-torteneti-gyujtemeny.t.125? $\mathrm{m}=28,2019.12 .10$

48 JANKovics-Kovács-SZABó-VIncZe (2017: 16-18; 77). 
könyvei, érmei, különféle tárgyai és eszközei. Az egyetem egykori és jelenlegi otthonának, alapítóinak, újjáalkotójának, rectorainak, dékánjainak, tanárainak [...] irodalmi möködése könyvekben, esetleg fontosabb kéziratokban, az egyetemre vonatkozót irodalom, kapcsolatban az egyetem életének és szervezetének történeti kifejlődését felölelő emlékekkel. [...] Jelen indítványommal csak általánosságban akartam rámutatni ama nagy kötelességre, mellyel szeretett Alma Materunknak tartozunk. Az egyetemi tanár felelössége tudatában és a magyar müvelődéstörténet professorának a nemzeti múltért hevülő lelkével indítványozom a tekintetes Egyetemi Tanácsnak, határozza el, hogy Tudományegyetemi Muzeumot szervez. ${ }^{49}$

Annak ellenére, hogy az Egyetemi Tanács támogatta a múzeum felállítását, amely a javaslat alapján mind egyedi tárgyakat, mind oktatási eszközöket tartalmazott volna, kiegészítve tanári hagyatékokkal és publikációkkal, nem sikerült megvalósítani az elképzelést. Ugyan számos egyetemtörténeti kiállítást szerveztek az elmúlt több mint 100 évben, de ezek csak időszakosak voltak és általában valamely jubileumhoz kötődtek. Például 1935-ben az egyetem alapításának 300. évfordulójára az Egyetemi Könyvtár díszterme adott otthont egy jubileumi kiállításnak, melyen Serédi Jusztinián bíboros hercegprímás is részt vett. ${ }^{50}$

A javaslatban is említett levéltári dokumentumok esetében sem történt áttörő változás a két világháború között sem. 1951-ben azonban az egyetem beszolgáltatta iratait a Magyar Országos Levéltárba, ahol 1956-ban bombatalálat következtében elégtek a 18-19. századi irat- és anyakönyvsorozatok. A megmaradt források felmérését és összegyüjtését 1957-ben javasolta Mátrai László, az Egyetemi Könyvtár föigazgatója. Javaslata nyomán megalakult az Egyetemi Levéltár, melynek gyüjtőkörébe egyetemi múzeum híján az egyetem történetének tárgyi emlékei azóta is beletartoznak. ${ }^{51}$

Az itt felvázolt nehézségek azonban nem csak az ELTE-n, nem csak a magyar egyetemeken figyelhetők meg. Az egyetemi gyüjtemények elsődleges feladata az anyaintézményben folyó oktatás és kutatás támogatása, míg az egyetem feladata az oktatás biztosítása. Ennek megfelelően az elavult tárgyakat felvonultató múzeumok fenntartásához az intézmények gyakran nem tudják biztosítani a múzeumi törvényi regisztrációhoz szükséges pénzügyi, szakmai,

49 SzÖGI-VARGa (2008: 8).

50 ELTE Egyetemi Könyvtár és Levéltár, Egyetemi Levéltár. Egyetemtörténeti Gyüjtemény, 2010.48.3.

51 SzÖGI-VARGA (2008: 10). 
szakemberi és nyilvánosságot biztosító feltételeket. Noha ezek a tárgyak értékesek, a nemzeti és a nemzetközi múlt emlékei, gyakran unikális darabokkal, amelyek különböző, elsősorban intézményi identitások alapjai, általában nem kapnak kellö figyelmet.

Az ICOM-UMAC (International Committee of University Museums and Collections) megpróbál lehetőséget teremteni arra, hogy a problémákra nemzetközi szinten tegyenek megoldási javaslatokat, az egyetemi múzeumok és gyüjtemények nemzetközi szinten is láthatóak legyenek, s párbeszédbe kezdhessenek. A különböző intézmények múzeumi regisztráció hiányában másmás stratégiát dolgoztak ki az intézményen belüli kezelés koordinálására.

A továbbiakban a múzeumi és gyüjteményi integráció lehetséges formái közül mutatok be néhányat egy-egy európai egyetem példája alapján.

\section{Egyetemi gyüjtemények összevonása}

Ez a modell a gyüjtemények egy (közös) struktúrába tömörítését jelenti, fizikai mozgatással. Az intézmény gyűjteményeinek megőrzése szempontjából ez számít a legoptimálisabb megoldásnak, hiszen így egy-két épületben alakítandók ki a megfelelő raktározási és kiállítási feltételek. További pozitívuma, hogy mind a szervezési, mind az irányítási kérdések egyszerüsödnek. Tehát az egy (vagy legfeljebb két) épületben való kialakítás során látványos egységgé válik az egyetemi múzeum, könnyebb a célközönség figyelmét ráirányítani. Azonban nem elhanyagolható negatívum, hogy a különböző gyüjtemények így az eredeti helyükröl elmozdítva, kontextusukból kiragadva éppen az elsődleges szerepükből, az oktatási funkcióból veszítenek.

Ilyen modellt alkalmaztak például a norvégiai Bergeni Egyetemen. Az egyetemi struktúrába illeszkedik a törvényi regisztrációval bíró egyetemi múzeum. Az intézmény összes gyüjteménye két épületben került elhelyezésre. Az egyikben a kulturális örökség kapott helyet, míg a másik épületben és a botanikus kertben a természettudományi gyüjtemények látogathatók. ${ }^{52}$

Másik északi példa az Uppsalai Egyetem gyüjteményi összevonása. Míg a Gustavianumnak nevezett egyetemi múzeum a numizmatikai és müvészeti gyüjteményt egyesíti, addig maga a múzeum is része egy nagyobb koordinációs egységnek. Az Uppsala University Culture and Heritage (szabad fordításban Uppsalai Egyetemi Kultúra és Örökség) elnevezésű szervezeti egység több egyetemi múzeumot és gyüjteményt is magába foglal: a botanikus kertet csakúgy, mint a jazz zenekart. ${ }^{53}$

52 Bergeni Egyetemi Múzeum szervezete, https:/www.uib.no/en/universitymuseum/65019/organisation, 2019. 12. 10

53 Uppsalai Egyetem Gustavianum szervezete, https://www.gustavianum.uu.se/about-us/organisation/, 2019.12.10. 
Közös koordináció, in situ megörzéssel

Ebben az esetben a gyüjtemények eredeti őrzési helyükön maradnak, azonban egy közös koordináció kialakítása révén lehetővé válik, hogy egységes figyelmet, kezelést és bemutatási lehetőségeket kapjanak a különböző gyüjtemények.

Ez a közös koordináció többféleképpen jelentkezhet, mindegyiknek azonban alapja, hogy a gyüjteményeket nem mozdítják el az elsődleges felhasználási helyről. Ez egyrészt a gyüjteményeknek az oktatásban betöltött szerepe miatt fontos, másrészt a kiállítások szempontjából is hasznos, hiszen eredeti kontextusukban lehet bemutatni a modern kor kívánalmainak megfelelöen az egyes gyüjteményeket. A közös koordináció kialakítása pedig optimális esetben megteremti azt a helyzetet, hogy amennyiben ugyan a tanszékek szakmai szempontokat figyelembe véve, fizikailag maguknál tartják a gyüjteményeket, de a fenntartás, a kiállítások és a nyilvános közzététel menedzselése, valamint a megfelelö raktározási viszonyok kialakítása egy közös, kari/ magasabb oktatási szervezethez tartozó egységhez kerül. A továbbiakban két európai példán keresztül röviden összefoglalom, hogy milyen megoldások születtek a közös koordináció kivitelezéséhez kapcsolódóan.

A skóciai Aberdeeni Egyetemen két múzeum is müködik, mert mindkét college kialakította a sajátját a profiljának megfelelően. Ezek az intézmény többi közgyüjteményéhez hasonlóan egy gyüjteményi igazgatóság koordinációja alá tartoznak. ${ }^{54}$

A fenti példához hasonló a Bécsi Egyetem megoldása is, azonban itt az egyetemi könyvtári szervezeten belül hozták létre a közös koordináció feladatait ellátó szervezeti egységet. A Sammlungskoordinierung elnevezésủ szervezeti egység legfontosabb feladata, hogy az Egyetemi Könyvtáron keresztül interdiszciplinális közvetítőként müködjön az egyetemi adminisztráció/vezetés és az egyetemi gyüjtemények között, valamint biztosítsa az egyetemi gyüjtemények hálózatát. A gyüjtemények közötti kommunikáció elősegítése és a gyüjteménytalálkozók szervezése mellett a Gyüjteményi Koordináció további alapfeladatai közé tartozik az egyetemi gyüjtemények teljes áttekintése, ehhez a gyüjteménykezelők, helyszínek, kiállítások, intézményi kapcsolatok nyilvántartásának létrehozása és kezelése (Sammlungsverzeichnis). Az egyetem kulturális javainak teljes körü felmérése után a gyüjteményi koordinátor feladata a gyüjtemények kezelésére vonatkozó egységes elöírások kidolgozása.

$54 \mathrm{Az}$ Aberdeeni Egyetem múzeumainak története, https://www.abdn.ac.uk/museums/documents/ University_of_Aberdeen_Museums_history.pdf, 2019.12.10. 
A későbbiekben további koordinációs tevékenység az egyetemi szintü gyüjtési stratégia és a gyűjtési politika kidolgozása és végrehajtása az egyetemi adminisztrációval való kapcsolattartás jegyében. Emellett a gyűjteményi koordinátor feladata, hogy a kulturális javak biztonságos és az állománynak megfelelő tárolásában támogassa a gyüjteménykezelőket, valamint összehangolja a megfelelö raktározási körülmények kialakításának és fenntartásának igényeit és a rendelkezésre álló erőforrásokat. További segítséget nyújt a gyüjteményeknek a kulturális javak szakmai nyilvántartásba vételében, valamint közremüködik a kiállítások, szállítások és kölcsönzések lebonyolításában.

A Bécsi Egyetemen alkalmazott gyüjteményi stratégiában nem kapott helyet a törvényi regisztráció, a különböző szervezeti egységekben és tanszékek keretén müködö egyetemi gyüjtemények két típusként kerülhetnek be a gyüjteményi nyilvántartásba: aktívan használt (van gyüjteménykezelö), valamint zárt gyüjteményekként. ${ }^{55}$

\section{Virtuális egyetemi múzeum}

A harmadik integrációs forma annyiban nem illeszkedik az eddig tárgyalt modellekhez, hogy a virtuális egyetemi múzeum létrehozható közös koordinációs rendszer kiépítése mellett vagy helyette is, ugyanis elsődleges felhasználási lehetősége, hogy a helyi széttagoltság mellett ebben a formában teljeskörüen bemutatható az egyetem szellemi és tárgyi vagyona. Akár szükítve a bemutatott gyüjteményeket, akár interdiszciplináris módon pedig olyan tárgyegyüttesek is összehozhatók a virtuális térben, melyek illeszkednek a koncepcióhoz, de a valóságban ritkán lehet megszemlélni őket együtt.

A digitalizált müvek bemutatásának számos más elönye is létezik. A virtuális térben lehetőség van arra, hogy láttatni lehessen a szabad szemmel felfoghatatlant, például jelenségeket, kísérleteket, vagy olyan tárgyakat, amelyek a valóságban csak tudományos eszközökkel érzékelhetőek. Továbbá természetesen a szabad szemmel látható tárgyak is alaposabban megszemlélhetők, forgathatók, de akár kiegészíthetők is. További előnye, hogy a látogató dönthet, mennyi plusz információt akar tudni. ${ }^{56}$

A legjelentősebb múzeumi digitalizációs vállalkozás a Google Art Project, melyhez hasonló technológiát már más cégek is alkalmaznak Magyarországon is.

55 Claudia Feigl gyüjteményi koordinátor szóbeli közlése alapján.

56 A Princeton Egyetem Mủvészeti Múzeuma számos stílusban készült virtuális kiállítást és interaktív játékot tesz közzé online. Például egy amerikai portrén való nyomkeresés során kérdésekre kell válaszolni a festmény részleteit illetően az interaktív megismeréshez. http://artmuseum.princeton.edu/ legacy-projects/portrait/portrait.html, 2019. 12. 10. 
A Google Térkép szoftver „Utcakép” (Street view) funkciója segítségével a világ jelentős múzeumainak mütárgyai tekinthetők meg „valóságos” múzeumi környezetben. Amennyiben nagy felbontásban készülnek el a felvételek, úgy a képek eddig nem látott részletei is megmutathatóakká válnak, valamint ez a technológia lehetővé teszi egy müemléki környezet virtuális bejárását is. Hátrány azonban, hogy a virtuális tér kezelhetősége nem feltétlenül könnyü, illetve ez a technológia csupán a valóságban megtekinthető kiállítások statikus leképezése, amelyben mozogni lehet, de plusz információval vagy interaktivitással nem minden esetben tud szolgálni.

Ezzel szemben virtuálisan létrehozhatók kiállítások; az ún. virtuális múzeum angol elnevezései a müfaj három legfontosabb típusára utalnak:

- digital museum: valódi tárlatok/gyüjtemények virtuális mása oly módon, hogy válogatást ad a valóságban is megtekinthető tárgyakból, így inkább virtuális kiállítási katalógusként vagy gyüjteményi adatbázisaként funkcionál. ${ }^{57}$ Tartalmazhat moderált interaktív lehetőségeket is, például a látogató saját digitális dokumentumaival gazdagíthatja a bemutatott gyüjteményt.

- online museum, electronic museum, cybermuseum, Web museum: csak a virtuális térben létező kiállítás, amelynek tárgyait gyakran több gyüjtemény őrzi. Felhasználásában hasonlít az elözőhöz, azonban egy adott koncepció alapján összegyüjtött tárgyakat mutat be egy virtuálisan felépített térben, melyekhez interaktív múzeumpedagógiai elemek társíthatóak. $^{58}$

- hypermuseum: olyan müveket, kiállításokat mutat be, amelyek csak a virtuális térben léteznek (pl. net art: kollektív vagy egyéni, csak digitális formában létező alkotások; virtuális valóság: digitális eszközökkel felépített mikrovilágok; kiterjesztett valóság: valós helyszínek vagy tárgyak fotójához csatolt virtuális tartalom). ${ }^{59}$

57 Például a Coimbrai Egyetem reprezentatív gyűjteményi adatbázisa, http://museudaciencia. inwebonline.net/?hasFlash=true\&, 2019. 12. 10.

Vagy a Princeton Egyetem Mủvészeti Múzeumának ázsiai gyüjteménye, http://artmuseum.princeton. edu/asian-art/about/, 2019. 12. 10.

58 Az Aberdeeni Egyetemen meghirdetett Connecting Collections elnevezésű projekt azt kéri a szakmai közönségtől, az egyetem polgáraitól és a látogatóktól, hogy keressék meg azokat a kapcsolódási pontokat, ahol az egyetemi múzeumok, levéltárak és könyvtárak anyagai egy-egy téma mentén kapcsolódni tudnak egymáshoz, az eredményeket pedig egy adatbázisban teszik közzé. Ezt már csak egy lépés, a bemutatás megváltoztatásának módja választja el a virtuális kiállítástól.

https://www.abdn.ac.uk/museums/collections/connecting-collections-427.php, 2019.12.10.

59 Például mindezt egyesíti az Aberdeeni Egyetem virtuális sétája az egyiptológiai gyüjtemény bemutatására. Ennek keretén belül az eredeti helyszínt és raktárakat fényképezték le 3D-ban, azonban hozzácsatoltak egy virtuális formában létrehozott sírt a fontosabb tárgyak bemutatásával. Amennyiben 
Nem elhanyagolható szempont, hogy a virtuális kiállítás minden eleme könynyen módosítható és bővíthető, az új szerzemények és felismerések integrálása egyszerübb és olcsóbb, mint egy valódi tárlat esetében. Emellett a digitalizált/ virtuális kiállításokkal el lehet érni azt a közönséget, amely elsősorban online forrásokon keresztül tájékozódik, és a kultúrát is ilyen módon fogyasztja. Az internetre kiterjesztett vagy csak ott létező kiállítás megtervezésekor tehát a szakszerüség és élményszerüség mellett az oktatási szempontokat fontos figyelembe venni, a multimédia pedagógia lényege pedig az interaktivitás. A személyessé tétel pedig tovább mélyíti a tudást azáltal, hogy a szabad böngészést, a saját látogatói utak kialakítását lehetővé teszi. De akár több narratíva megjelenítése is lehetséges azonos tárgyegyüttesben: a kurátor, a kutató és a látogató saját interpretációi egymást gazdagítják.

\section{Összegzés}

Tanulmányom szük kereteinek figyelembevételével annak első részében vázlatosan összefoglaltam az ELTE kulturális javainak, tudományos és oktató gyüjteményeinek alapítását és sorsát, összekapcsolva az egyetemtörténeti fordulópontokkal, nemzetközi kontextusba helyezve azokat. A tanulmány második felében néhány példát felvillantva a világ minden tájáról - hiszen az online térben ez is lehetséges - bemutattam három lehetséges integrációs formát az egyetemi múzeumok és gyüjtemények számára. Célom az volt, hogy rávilágítsak arra, hogy az egyetemi örökség kérdése a történeti múlttal rendelkező egyetemeken jelen van, s igen nagy hasonlóságok mutathatók ki az egyetemi gyüjtemények sorsában, valamint hogy az intézményi sajátosságok figyelembevételével más és más stratégiákat dolgoztak ki az egyetemi gyüjtemények kezelésére és koordinációjára, amelyek az ELTE gyüjteményi koordinációjában is alkalmazhatóak.

A szakirodalom áttekintésekor két, külföldi szerző által megállapított modellt mutattam be, amelyek sok európai egyetem gyüjteményeinek és múzeumainak vizsgálata segítségével összegezték a gyüjtemények történeti kialakulásának típusait, valamint az egyetemi múzeumok mint integrációs formák kialakulásának történeti síkjait is meghatározták. Az ELTE alapításának, néhány reprezentatív - a Lorenco-féle modell egy-egy típusára reflektáló egyetemi gyüjteményének és alapításához köthető kulturális javainak bemutatásával azt szerettem volna kiemelni, hogy az ELTE története során milyen

ezekre a virtuális tárgyakra rákattintunk, úgy az eredeti tárgyak forgatható, 3D-s modelljét és leírását tekinthetjük meg.http://www.mercury92.com/AU-Museums/Egypt.html, 2019. 12. 10. 
szervesen illeszkedik fejlődésében és nehézségeiben az európai egyetemekhez. A különböző tisztségjelvények, a botanikus kert, az ELTE Természetrajzi Múzeumának gyüjteményei, valamint Eötvös Loránd szertárának darabjai - melyek 2019. november 22. és 2021. május 22. között megtekinthetőek az ELTE Egyetemi Könyvtár és Levéltár „A pontosság büvöletében - Eötvös Loránd élete és munkássága" címủ időszakos tárlaton - mind az egyetemi kulturális örökség részét képezik, az egyetemi múlt egy-egy különleges darabjaként.

A múltdarabkák közös koordinációjára számos próbálkozás, modell létesült az európai egyetemeken, melyeket egymástól tanultak el vagy az intézményi sajátosságok figyelembevételével alakította ki. Ezek közül mutattam be néhányat, amelyek az egyetemi múzeumoktól kezdve az egyetemi gyüjtemények koordinációs szervezetei egységein keresztül egészen a virtuális térben létező múzeumok és kiállításokig igen széles palettát ölelnek fel.

\section{Irodalomjegyzék}

Borsodi $2003=$ Borsodi Cs.,

Az egyetem a XX. század második felében 1945-2002, in: Szögi L. (ed.), Az Eötvös Loránd Tudományegyetem története 1635-2002, Budapest, 2003, 305-382.

Buday-Budayné 1986 = Buday T. - Budayné Mosonyi K., „A fizika fejedelme”. Eötvös Loránd élete és munkássága, Budapest, 1986.

Clercq 2006 = S. W. G. De ClercQ,

Keeping for the future, in: S. Waltos (ed.), Opuscula Musealia 15, Krakkó, 2006, 23-30.

Clercq 2009 = S. W. G. De ClercQ,

The role of university museums in documenting contemporary research, in: S. Waltos (ed.), Opuscula Musealia 17, Krakkó, 2009, 13-21.

FARKAS $2008=$ FARKAS G. F.,

Az Egyetemi Könyvtár a jezsuita rend kezelésében (1561-1773), in: Szögi L. (ed.), Az Egyetemi Könyvtár története és gyüjteményei, Budapest, 2008, 7-32.

GYöRY 1936 = GYöRY T.,

Az orvostudományi kar története 1770-1935, Budapest, 1936.

HöGYES 1896 = HöGYES E.,

Emlékkönyv a budapesti királyi magyar tudományegyetem orvosi karának múltjáról és jelenéről, Budapest, 1896.

Jankovics-Kovács-Szabó-Vincze 2017 =Dr. Jankovics I. - Dr. Kovács J. - Dr. Szabó M. Gy. DR. VINCZE I.,

Az ELTE Gothard Asztrofizikai Obszervatórium története képekben, Budapest, 2017.

KNAPP-SZÖGI 2012 = KNAPP É. - SzÖGI L.,

Az Eötvös Loránd Tudományegyetem Egyetemi Könyvtára, Budapest, 2012. 
Laurenco $2005=$ M. C. Laurenco,

Between two worlds: The distinct nature and contemporary significance of university museums and collections in Europe, Phd disszertáció, Párizs, 2005.

https://webpages.ciencias.ulisboa.pt/ mclourenco/, 2019. 12. 10.

MAdAS-MonoK 1998 = MAdAs E. - MonOK I.,

A könyvkultúra Magyarországon a kezdetektől 1730-ig, Budapest, 1998.

MAJLÁTH 1899 = MaJláTH B.,

A nagyszombati egyetemen kiadott doktori oklevél 1642-böl, Turul, 138 (1899), 144.

MiKonya 2014 = MiKonya Gy.,

Az európai egyetemek története (1230-1700), Budapest, 2014.

PAPP 1982 = PAPP J.,

Hagyományok és tárgyi emlékek az Eötvös Loránd Tudományegyetemen, Budapest, 1982.

SASHEGYi 2003 = SASHEGYi O.,

Az egyetem az önkényuralom korában 1849-1867, in: Szögi L. (ed.), Az Eötvös Loránd Tudományegyetem története 1635-2002, Budapest, 2003, 165-202.

SCHMIDT 2013 = SCHмIDT Á. J.,

A Tudományegyetem Campusai. Az Egyetem téri telep és a Múzeum körúti Campus kialakulása és története a dualizmus időszakában, Első Század, 2013. nyár, 95-110.

Sinkovits 2003 = Sinkovits I.,

A nagyszombati egyetem 1635-1777, in: Szögi L. (ed.), Az Eötvös Loránd Tudományegyetem története 1635-2002, Budapest, 2003, 15-70.

SPENCER-Cross $2014=$ R. SPENCER - R. Cross,

The origins of botanic gardens and their relation to plant science, with special reference to horticultural botany and cultivated plant taxonomy, Muelleria, 32 (2014), 43-93.

SZEITZ 2013 = SZEITZ P.,

Az ELTE Öslénytani Tanszék gyüjteményeinek története, Földtani Közlöny, 143/4 (2013), 383-394.

SzÖGI-VARGA 2008 = SzöGI L. - VARGA J., Az Eötvös Loránd Tudományegyetem levéltára, Budapest, 2008. 


\section{Felhasznált források}

\section{Levéltári}

- II. Ferdinánd császár egyetemalapítást megerősítő okvele, 1635.

október 18. ELTE Egyetemi Könyvtár és Levéltár, Egyetemi

Levéltár. I/c-III. Rektori Hivatal iratai. Alapítólevelek.

- Az egyetem első zászlója, 1635k. ELTE Aula Magna.

- Az egyetem nagypecsétje a Pestre költözés után. ELTE Egyetemi Könyvtár és Levéltár, Egyetemi Levéltár. Egyetemtörténeti Gyüjtemény. Képessy Bence felvétele.

- A botanikus kert főépülete, ELTE Egyetemi Könyvtár és Levéltár, Egyetemi Levéltár. Egyetemtörténeti Gyüjtemény, 2008.239.1.

- Bölcsészettudományi Kar dékáni lánca, 1819. MNM Történeti Tár, Ötvösgyüjtemény. Ltsz. 19.I.12./1949.

- Bölcsészettudományi Kar peduma, 1635k. MNM Történeti Tár, Ötvösgyüjtemény. Ltsz. 1949.20.

- Diploma Inaugurale, 1780. március 25. ELTE Egyetemi Könyvtár és Levéltár, Egyetemi Levéltár. I/c-III. Rektori Hivatal iratai. Alapítólevelek.

- Jogi Kar peduma, 1667, MNM Történeti Tár, Ötvösgyűjtemény. Ltsz. 1949.19.

- Jubileumi kiállítás 1935-ben. ELTE Egyetemi Könyvtár és Levéltár, Egyetemi Levéltár. Egyetemtörténeti Gyüjtemény, 2010.48.3.

- Múzeum a Trefort-kertben. Királyi Magyar Tudományegyetem épületei, 1. kötet. Divald Károly fotója.

- A múzeum háború utáni romos állapota. ELTE Egyetemi Könyvtár és Levéltár, Egyetemi Levéltár. Egyetemtörténeti Gyűjtemény, 2008. 258. 3.

- Orvosi Kar peduma, 1770. Semmelweis Egyetem, Rektori Hivatal.

- Pázmány Péter alapító oklevele, 1635. május 12. ELTE Egyetemi Könyvtár és Levéltár, Egyetemi Levéltár. I/c-III. Rektori Hivatal iratai. Alapítólevelek.

- Rektori pedum, 1635k. MNM Történeti Tár, Ötvösgyüjtemény. Ltsz. 1949.17.

- Teológiai Kar peduma, 1635k. Pázmány Péter Katolikus Egyetem Hittudományi Kar.

- A Trefort-kert D épülete. Királyi Magyar Tudománegyetem épületei, 1. kötet. Divald Károly fotója.

- A Fizikai Intézet új épületének demonstrációs szertára 1900-ban. A Trefort-kert D épülete. Királyi Magyar Tudománegyetem épületei, 1. kötet. Divald Károly fotója.

\section{Online}

- Aberdeeni Egyetem, Connecting Collections elnevezésú,

- https://www.abdn.ac.uk/museums/collections/conecting-collections-427.php, 2019.12.10.

- Aberdeeni Egyetem, egyiptológiai gyüjtemény,

- http://www.mercury92.com/AU-Museums/Egypt.html, 2019. 12. 10. 
- Bergeni Egyetemi Múzeum szervezete,

https://www.uib.no/en/universitymuseum/65019/organisation, 2019. 12. 10

- Például a Coimbra-i Egyetem reprezentatív gyüjteményi adatbázisa, http://museudaciencia.inwebonline.net/?hasFlash=true\&, 2019. 12. 10.

- ELTE Bárczi Gusztáv Gyógypedagógiai Kar Gyógypedagógiai-történeti Gyüjtemény https://barczi.elte.hu/content/gyogypedagogia-torteneti-gyujtemeny.t.125?m=28, 2019.12.10

- Princeton Egyetem Múvészeti Múzeuma, http://artmuseum.princeton.edu/legacy-projects/portrait/portrait.html, 2019. 12. 10.

- Princeton Egyetem Múvészeti Múzeumának ázsiai gyüjteménye, http://artmuseum.princeton.edu/asian-art/about/, 2019. 12. 10. 